\title{
A study of coronary artery disease in young patients
}

\section{Badanie służące ocenie występowania choroby wieńcowej w młodym wieku}

\author{
Sabiye Yılmaz ${ }^{1}$, Hüseyin Gündüz ${ }^{1}$, Perihan Varım ${ }^{1}$, Mehmet Bülent Vatan ${ }^{1}$, Saadet Demirtaş ${ }^{1}$, \\ Mehmet Akif Çakar ${ }^{1}$, Ercan Aydın ${ }^{2}$, Ersan Tatı ${ }^{1}$, Mustafa Tarık Ağaç ${ }^{1}$ \\ ${ }^{1}$ Sakarya University Education and Research Hospital, Department of Cardiology, Sakarya, Turkey \\ ${ }^{2}$ Trabzon Vakfıkebir Devlet Hastanesi, Cardiology, Trabzon, Turkey
}

\section{Abstract}

Introduction. An increasing number of younger patients are being hospitalized with acute coronary syndromes. Earlier risk assessment is essential to prevent or delay coronary artery disease (CAD). This study aimed to assess the rate, risk factor profile, presentation, management and prognosis in young patients with CAD and compared with the same age group without CAD.

Material and methods. In this retrospective study, 4325 patients who had undergone coronary angiography from 2011 to 2014 were identified. A total of 627 patients were $\leq 45$ years age; 412 of them had CAD, and 215 had normal coronary arteries (control group).

Results. The mean age of the patients was $41.7 \pm 4.1$ years in the CAD group and $41.5 \pm 4.5$ years in the control group. The prevalences of dyslipidemia, smoking, family history of CAD, hypertension, diabetes, and overweight were higher in the CAD than in the control group. However, the obesity rate was not significantly different between the two groups. Patients with ACS often presented with ST elevation myocardial infarction (STEMI) (49.3\%), and single-vessel involvement (55.3\%) predominated. Percutaneous coronary intervention ( $\mathrm{PCl}$ ) was the main myocardial reperfusion therapy (68.4\%).

Conclusions. Among the young patients studied, CAD had a higher incidence in males. Smoking was the most important modifiable risk factor. Also, patients showed high prevalences of dyslipidemia, overweight, diabetes, and family history of CAD. This study re-emphasizes the relationship between traditional cardiovascular risks and CAD in young.

Key words: coronary artery disease, young adults, coronary angiography

Folia Cardiologica 2017; 12, 6: 543-550

\section{Introduction}

Coronary artery disease (CAD) is one of the main causes of morbidity and mortality worldwide. Although this condition usually afflicts older people, an increasing number of younger patients are being hospitalized with acute coronary syndromes (ACS). The prevalence of coronary atherosclerosis in young adults is difficult to estimate. However, several studies have described the clinical profiles and outcomes of young adults, among which the incidence of the disease has been reported to range between $4 \%$ and $10 \%$ [1-4]. Earlier risk assessment for effective cardiovascular disease prevention is essential to prevent or delay coronary calcification, which has been shown to predict subsequent coronary heart disease. In general, young patients are more likely to be male and to have a history of smoking, hyperlipidemia, and cocaine use but are less likely to have other comorbidities, such as hypertension, 
diabetes mellitus (DM), or prior CAD [1, 2, 5-10]. We therefore investigated the CAD frequency, risk factors, presenting symptoms, treatment, angiographic findings, implications, and in-hospital outcomes among young patients undergoing coronary angiography in our hospital.

\section{Materials and methods}

Study population in this retrospective study included 4325 patients who had undergone coronary angiography in our hospital from 01 January 2011 to 30 September 2014. A total of 627 patients were $\leq 45$-years-old and had ACS or stable angina pectoris with ischemia documented by exercise testing or myocardial perfusion scintigraphy. The cutoff age of 45 years has been previously used to define young patients. A total of 412 young patients showed coronary artery stenosis in the initial angiogram, and 215 patients had normal coronary arteries. We compared those patients who had CAD (CAD group) with those who showed normal coronary arteries (control group).

Data on the patients'demographic characteristics, risk factors, presenting signs and symptoms, blood investigation, number of diseased coronary vessels, ejection fraction (EF), complications, and in-hospital outcomes were retrospectively collected from clinical records and analyzed. The ACS definition included ST elevation myocardial infarction (STEMI), non-ST elevation myocardial infarction (NSTEMI), and unstable angina (UA). Coronary angiography was done in all patients because of ACS or stable angina with ischemia documented by exercise testing or myocardial perfusion scintigraphy. Also, coronary angiography was done to investigate the etiology of heart failure and arrhythmia. Angiographic stenosis was defined as a $70 \%$ or greater decrease in the diameter of a major epicardial coronary vessel or a decrease greater than $50 \%$ in the diameter of the left main coronary artery (LMCA). DM was defined as history of DM treated with medication, or a fasting blood glucose level of $126 \mathrm{mg} / \mathrm{dL}$ or two casual plasma glucose readings of $200 \mathrm{mg} / \mathrm{dL}$. Hypertension was defined as blood pressure greater than $140 \mathrm{~mm} \mathrm{Hg}$ systolic or $90 \mathrm{~mm} \mathrm{Hg}$ diastolic on at least two occasions or receiving any antihypertensive drug. Hyperlipidemia was defined as history of dyslipidemia diagnosed and/or treated, low-density lipoprotein (LDL)-cholesterol greater than or equal to $130 \mathrm{mg} / \mathrm{dL}$, high-density lipoprotein (HDL)-cholesterol $<40 \mathrm{mg} / \mathrm{dL}$ in men or $<50 \mathrm{mg} / \mathrm{dL}$ in women, or hypertriglyceridemia ( $\mathrm{TG} \geq 150 \mathrm{mg} / \mathrm{dL}$ ). Current smoker was defined as a person who smoked cigarettes within 1 month. A family history of CAD was defined as evidence of CAD in a parent, sibling, or children before 55 years of age. Overweight was defined as body mass index (BMI) greater than $25 \mathrm{~kg} / \mathrm{m}^{2}$, and obesity as BMI greater than $30 \mathrm{~kg} / \mathrm{m}^{2}$. Renal impairment was defined as serum creatinine $\geq 2 \mathrm{mg} / \mathrm{dL}$. Echocardiographic assessment of the left ventricular fun- ction was done in all patients. The results were classified according to systolic function as normal (LVEF $\geq 50 \%$ ), mild-moderate LV dysfunction (LVEF of 35-50\%), or severe LV dysfunction (LVEF < 35\%).

The major clinical outcomes (in-hospital and long-term) analyzed in our study included all cause mortality, congestive heart failure (New York Heart Association classes II-IV), recurrent ischemia/reinfarction, major arrhythmic events, cardiogenic shock, major bleeding, and stroke.

The study was approved by the local ethics committee.

\section{Statistical analysis}

Continuous variables were expressed as mean \pm SE of mean. Dichotomous variables were expressed as counts and percentages. Differences in baseline characteristics were compared by using Student's $t$ test and the $x^{2}$ test. Calculations were done with the use of the SPSS software (version 16.0; SPSS, Inc., Chicago, Illinois). All P values were 2-sided and considered statistically significant at $P<0.05$.

\section{Results}

\section{Clinical characteristics}

The mean ages at presentation were $41.7 \pm 4.1$ and 41.5 \pm 4.5 years in the CAD and the control group, respectively. Tables 1 and 2 show the baseline clinical characteristics and laboratory findings for the study population. Patients with CAD were more likely to present with chest pain (95.6\%) and less likely to have heart failure (Killip classes II to IV in 3.4\%) and arrhythmia (1\%). There was no significant difference between the two groups regarding age, blood pressure and heart rate at first admission, BMI, LDL values, and hypertension. The young patients with CAD had higher prevalences of smoking, male gender, family history of CAD, DM, previous CAD, and TG values but showed lower HDL levels. A few patients had a history of peripheral artery disease, prior cerebral stroke, and chronic renal failure. The prevalence of overweight was higher among young patients with CAD than in the control group ( $p=0.008)$, whereas the difference in the prevalence of obesity between the two groups was not statistically significant $(p=0.188)$. Diabetes was more frequent in the CAD group $(p<0.001)$, and patients with CAD had higher serum glucose levels $(p=0.00)$ at first admission. The mean troponin-l level in the CAD group was $22.8 \pm 33.1 \mu \mathrm{g} / \mathrm{L}$. Echocardiography during hospitalization revealed that the mean LV function was significantly decreased in patients with CAD compared with the control group $(p=0.00)$.

\section{Angiographic features}

The majority of patients in the CAD group presented with STEMI, with a slightly higher rate of anterior MI. The most patients had single-vessel disease and left main disease (LMCA). Based on the angiographic analysis, 35 patients 
Table 1. Baseline clinical characteristics for the study population

\begin{tabular}{|c|c|c|c|}
\hline Parameter & CAD group & Control group & $p$ \\
\hline Age & $41.7 \pm 4.1$ & $41.5 \pm 4.5$ & 0.505 \\
\hline Male [\%] & 349 (84.7) & $126(58.6)$ & 0.001 \\
\hline Body weight [kg] & $82.5 \pm 13.4$ & $79.2 \pm 15.3$ & 0.010 \\
\hline $\mathrm{BMI}\left[\mathrm{kg} / \mathrm{m}^{2}\right]$ & $28.2 \pm 3.7$ & $28.1 \pm 5.1$ & 0.990 \\
\hline Overweight [BMI $\left.\geq 25 \mathrm{~kg} / \mathrm{m}^{2}\right]$ [\%] & $310(83.8)$ & $123(74.1)$ & 0.008 \\
\hline Obesity $\left[\mathrm{BMI} \geq 30 \mathrm{~kg} / \mathrm{m}^{2}\right][\%]$ & $104(28.1)$ & $56(33.2)$ & 0.188 \\
\hline Smoking [\%] & $333(80.8)$ & $100(46.5)$ & 0.001 \\
\hline DM type II [\%] & $112(27.2)$ & $26(12.1)$ & 0.001 \\
\hline DM type I [\%] & $5(1.2)$ & 0 & 0.105 \\
\hline Hypertension [\%] & $122(29.6)$ & $46(21.4)$ & 0.029 \\
\hline Dyslipidemia [\%] & $334(81.1)$ & $141(65.6)$ & 0.001 \\
\hline Chronic kidney disease [\%] & $9(2.2)$ & 0 & 0.029 \\
\hline Previous CAD [\%] & $68(16,5)$ & 0 & 0.001 \\
\hline Heart failure [\%] & $54(13.1)$ & $10(4.7)$ & 0.001 \\
\hline History of CVA [\%] & $6(1.5)$ & 0 & 0.075 \\
\hline Family history [\%] & $132(33.8)$ & $61(23.2)$ & 0.020 \\
\hline Illegal drug use [\%] & $7(1.7)$ & 0 & 0.147 \\
\hline PAD [\%] & $6(1.5)$ & 0 & 0.075 \\
\hline \multicolumn{4}{|l|}{ Presentation [\%]: } \\
\hline - typical angina & $393(95.6)$ & 209 (97.2) & 0.030 \\
\hline - STEMI & $203(49.3)$ & & \\
\hline - NSTEMI & $100(24.2)$ & & \\
\hline - USAP & $83(20.1)$ & $128(59.7)$ & 0.001 \\
\hline - stable angina pectoris & $18(4.4)$ & $81(37.5)$ & 0.001 \\
\hline - Killip class II or IV & $15(3.4)$ & $3(1.4)$ & 0.001 \\
\hline - arrhythmias & $4(1)$ & $3(1.4)$ & 0.010 \\
\hline
\end{tabular}

BMI - body mass index; DM - diabetes mellitus; CAD - coronary artery disease; CVA - cardiovascular accident; PAD - peripheral artery disease; STEMI - ST-elevation myocardial infarction; NSTEMI - non-ST-elevation myocardial infarction; USAP - unstable angina pectoris

Table 2. Laboratory analysıs of the first hospital admission in the study population

$\begin{array}{lccc}\text { Laboratory analysis } & \text { CAD group } & \text { Control group } & p \\ \text { Hemoglobin }[\mathrm{mg} / \mathrm{dL}] & 14.4 \pm 5.4 & 14.6 \pm 10.3 & 0.808 \\ \text { Triglyceride }[\mathrm{mg} / \mathrm{dL}] & 214.9 \pm 177 & 173.1 \pm 133.4 & 0.003 \\ \text { HDL }[\mathrm{mg} / \mathrm{dL}] & 32.2 \pm 9.7 & 42.7 \pm 11.8 & 0.000 \\ \text { LDL }[\mathrm{mg} / \mathrm{dL}] & 131.3 \pm 43.2 & 125 \pm 36.2 & 0.600 \\ \text { CRP }[\mathrm{mg} / \mathrm{L}] & 12.9 \pm 21.7 & 9.8 \pm 19.2 & 0.439 \\ \text { Troponin } & 22.8 \pm 33 & 0.1 \pm 0.8 & 0.000 \\ \text { Glucose }[\mathrm{mg} / \mathrm{dL}] & 138 \pm 71 & 108 \pm 40 & 0.000 \\ \text { Creatıne } & 1.02 \pm 1.23 & 0.77 \pm 0.46 & 0.005 \\ \text { Echocardiography (LVEF) } & 48.3 \pm 9.6 & 57.1 \pm 7.8 & 0.000 \\ \text { Ejextion fraction }<35 \% & 54(13.1) & 10(4.7) & 0.001\end{array}$

$\mathrm{HDL}$ - high-density lipoprotein; LDL - low-density lipoprotein; CRP - C-reactive protein; LVEF - left ventricular ejection fraction 
Table 3. Coronary angiographic features, treatment and reperfusion strategies in patients with coronary artery disease (CAD)

$\begin{array}{lc} & \text { CAD group } \\ \text { Number of diseased vessels } & \\ \text { LMCA } & 3(0.7 \%) \\ \text { Single-vessel } & 230(55.3 \%) \\ \text { Two-vessel } & 107(26 \%) \\ \text { Multiple-vessel } & 28(6.8 \%) \\ \text { Minimal CAD } & 35(8.5 \%) \\ \text { Normal CAD } & 6(1.5 \%) \\ \text { Coronary artery ectasia } & 3(0.7 \%) \\ \text { Coronary slow flow } & 3(0.7 \%) \\ \text { Coronary reperfusion strategies } & \\ \text { Primary PCI } & 155(37.6 \%) \\ \text { Rescue PCl } & 10(2.4 \%) \\ \text { Elective } & 117(28.4 \%) \\ \text { Initial success of primary PCI } & 147(94.8 \%) \\ \text { Thrombolytic therapy } & 43(10.4 \%) \\ \text { Elective or emergent CABG } & 38(9.2 \%) \\ \text { Medical follow up } & 60(14.6 \%) \\ \text { Infarct-related artery in primary PCI } & \\ \text { LAD } & 94(60 \%) \\ \text { LCX } & 14(9.07 \%) \\ \text { RCA } & 47(30.3 \%)\end{array}$

LMCA - left main coronary artery; $\mathrm{PCl}$ - percutaneous coronary intervention; $\mathrm{CABG}$ - coronary artery bypass surgery; LAD - left anterior descending artery LCX - left circumflex artery; RCA right coronary artery

with ACS had less than $50 \%$ stenosis, and 6 patients with ACS had normal coronary arteries. Only one coronary artery anomalies (circumflex artery (CX) originating from the right coronary sinus) was identified. The angiography revealed normal coronary arteries with slow coronary flow in pregnant patient with inferior $\mathrm{Ml}$ who was admitted to the emergency department as a case of cardiopulmonary arrest. Also coronary artery dissection observed in the left anterior descending artery (LAD) in patient with 39-week pregnant. Although the mortality is higher in this patient group, she survived the three-year follow-up. Seven patients had a history of recreational drug use, but that may not be the exact number of social causes. Factor $\mathrm{V}$ Leiden mutation was identified in one patient.

The patients received revascularization treatments, including thrombolytic therapy (43 patients), $\mathrm{PCl}$ (282 patients), and CABG (38 patients). Primary PCl was the main myocardial reperfusion therapy in STEMI and was done in 155 patients (37.6\%). The success rate of percutaneous procedures was very high (approaching 97\%) in the young patients, and that of primary $\mathrm{PCl}$ was $94.8 \%$. Acute stent thrombosis occurred in 5 patients, and subacute stent throm- bosis was detected in 11 patients, complicating STEMI during hospitalization. The rescue $\mathrm{PCl}$ was applied in 10 patients. Elective or emergent CABG was needed in 38 patients, and 60 patients were treated medically. During the long-term follow-up, recurrent $\mathrm{MI}$ developed in 33 patients, 13 of whom showed chronic stent restenosis. Table 3 shows the angiographic findings, treatment, and reperfusion strategies.

\section{In-hospital outcome and discharge diagnosis} The duration of hospital stay in the CAD group was $4.1 \pm$ \pm 2.2 days. Sixty-nine patients $(16.7 \%)$ with STEMI in whom percutaneous angioplasty was done received glycoprotein Ilb/Illa inhibitors. The rates of complications and mortality were lower during the hospitalization period. Fourteen patients in the CAD group had heart failure (Killip classes II to IV); cardiogenic shock occurred in 3 of these patients, requiring intra-aortic balloon counterpulsation for hemodynamic support. The in-hospital mortality was low, with only 2 deaths. None of the young patients had contrast nephropathy, sepsis, LV mechanical complications, such as septum/free wall rupture, embolism, or stroke. The incidence of major arrhythmic events, especially ventricular arrhythmia, was 7.2\%. On discharge from the hospital, clinical heart failure required diuretics was considered in $54(13.1 \%)$ of the young patients with CAD although half of the patients with CAD had preserved LVEF. During the mean followup period of 27 months (range, 8-54 months), 33 patients (8.09\%) developed recurrent MI. Two patients developed apical thrombus, but none of the patients had a stroke. Table 4 shows the medical treatment and clinical outcomes of patients with ACS during their hospital stay and in the follow-up period.

\section{Discussion}

The prevalence of $\mathrm{CAD}$ in young patients have reported between 4\% and $10 \%$ depending on the cutoff age used; this is in accordance with the $9.52 \%$ prevalence in our study population [1-4]. The recently increased prevalance of CAD in young adults can be partly attributed to the increased prevalence of risk factors for atherosclerosis. Previous studies have reported that young patients with CAD had higher proportions of males, smoking, overweight, hyperlipidemia, and family history of CAD but lower incidences of hypertension and DM [1, 2, 5-10]. However, most of these studies compared young patients with older ones. Our study results were in accordance with those previous findings and reinforce the role of conventional risk factors in young patients. Male sex was more prevalent, and risk factors, such as tobacco use, overweight, hyperlipidemia, DM, and hypertension, were more frequent in young patients with CAD compared with the control group. In addition, the statistical significance was less determined between the two groups in terms of hypertension, and LDL-cholesterol. 
Table 4. Medical treatment and clinical outcomes in patients with acute coronary syndrome during their hospital stay and follow-up

\begin{tabular}{|c|c|}
\hline & CAD group \\
\hline \multicolumn{2}{|l|}{ Medical treatment } \\
\hline Glycoprotein Ilb/IIla inhibitors & $69(16.74 \%)$ \\
\hline Heparin & $155(37.6 \%)$ \\
\hline Low-molecular-weight heparin & $183(44.4 \%)$ \\
\hline Aspirin & $400(97.1 \%)$ \\
\hline Clopidogrel & $327(79.4 \%)$ \\
\hline ACEI/ARB & 288 (69.9\%) \\
\hline Beta-blocker & $324(78.8 \%)$ \\
\hline Statin & $335(81.5 \%)$ \\
\hline Diuretic & $25(6.06 \%)$ \\
\hline \multicolumn{2}{|l|}{ Hospital outcomes } \\
\hline Length of hospital stay [day] & $4.1 \pm 2.2$ \\
\hline In-hospital mortality & $2(0.4 \%)$ \\
\hline Ventricular arrhythmia & $24(5.8 \%)$ \\
\hline Atrioventricular block & $3(0.7 \%)$ \\
\hline Paroxysmal atrial fibrillation & $2(0.4 \%)$ \\
\hline Cardiac rupture/tamponade & 0 \\
\hline Bleeding complications & $2(0.4 \%)$ \\
\hline Acute renal failure & $1(0.24 \%)$ \\
\hline Infection & 0 \\
\hline \multicolumn{2}{|l|}{ Stent thrombosis } \\
\hline Acute & $5(1.2 \%)$ \\
\hline Subacute & $11(2.7 \%)$ \\
\hline Stroke & 0 \\
\hline \multicolumn{2}{|l|}{ Clinical heart failure } \\
\hline Killip I & $50(12.1 \%)$ \\
\hline Killip II-III & $12(2.7 \%)$ \\
\hline Cardiogenic shock & $3(0.72 \%)$ \\
\hline \multicolumn{2}{|l|}{ Long-term outcome } \\
\hline Repeated PCl & $31(7.5 \%)$ \\
\hline Chronic stent restenosis & $13(4.7 \%)$ \\
\hline Recurrent myocardial infarction & 33 (8.1\%) \\
\hline Overall mortality & $5(1.2 \%)$ \\
\hline Left ventricular apical thrombus & $2(0.5 \%)$ \\
\hline
\end{tabular}

ACEI - angiotensin-converting enzyme inhibitors; ARB - angiotensin receptor blockers; $\mathrm{PCl}$ - percutaneous coronary intervention

Cigarette smoking was found to be the most common modifiable risk factor. The role of smoking in the pathogenesis of $\mathrm{MI}$ in young people is well-established, with most studies reporting that between $75 \%$ to $90 \%$ of young patients with acute MI are smokers [1-5, 9]. In the Framingham Heart Study, Kannel et al. [11] found the relative risk for $C A D$ to be thrice higher in smokers of ages 35-44 years compared with nonsmokers. This was confirmed in the present study, in which $80.8 \%$ of the patients had a history of tobacco use, and the prevalence of smoking was more than twice as high among patients with CAD compared with controls.

The incidence of lipid abnormalities, especially high TG and low HDL cholesterol, was also a higher in patients with MI who were less than 45-years-old [4, 12, 13]. Fasting serum TG levels are usually inversely related to HDL levels, and hypertriglyceridemia is an independent risk factor beyond LDL cholesterol [4]. Thus, it can be concluded that high TG, which may be the primary lipid abnormality with or without low HDL levels and normal/high LDL levels in young adults, is a matter of concern. Also HDL-C are an important parameter for predicting the risk and the clinical outcomes of AMI in young male patients [13]. In our study, $81.1 \%$ of the patients had dyslipidemia. Although the LDL cholesterol level did not differ between the two groups, the TG concentration was higher and the HDL cholesterol level was lower in the CAD group, in accordance with previous findings $[4,12,13]$.

Overweight and obesity lead to many health conditions, such as DM, hypertension, hyperlipidemia, and heart disease [14]. Although overweight is not considered to be a certain risk factor for $\mathrm{Ml}$, it has been suggested to be a potential independent risk factor for $\mathrm{Ml}$ in a young population [15]. Although the frequency of obesity was not significantly different between two groups the prevalence of overweight was significantly higher in the CAD group. Thus, our results suggested that being overweight might be a potential risk factor for $\mathrm{Ml}$ in young populations.

The prevalence of DM in young patients was lower than in the non-young [6-9], moreover, it has been found to be frequently present in young CAD patients [14-16]. In this study, the prevalence of DM (mainly type 2) was twice as high in the CAD group than in the control group. In addition, the prevalence of DM was slightly higher compared with that reported in previous studies [6, 7]. Although insulin-dependent $\mathrm{DM}$ is a high risk factor for CAD, type $1 \mathrm{DM}$ was found only in 5 young CAD patients, a lower number than in previous studies $[14,16]$. Apart from overt diabetes, impaired glucose tolerance was found in $65 \%$ of $\mathrm{Ml}$ survivors less than 45 years old, as reported in a previous study [17]; however, there are no data related to insulin resistance in the present study.

Family history of premature $\mathrm{MI}$ is a factor known to be present in many of young patients and probably represent a combination risk factors of CAD that are genetically determined $[1,8]$. It has previously been shown that children whose family members had premature CAD tended to have greater insulin resistance, more lipid abnormalities, and higher incidences of obesity [18]. In a study carried out among young patients in London, positive family history was found in $39 \%$ of the participants [19]. Similarly, we 
found family history in 38\% of the patients; however, there was no statistically significantly difference between two groups.

Angina that rapidly progress to acute $\mathrm{Ml}$ is a common clinical presentation of CAD in young adults $[2,19]$. The prevalence of stable angina is rare; it was found to be $24 \%$ in only one study and the duration of symptoms was reported to be less than a week in most patients [19]. Our study results indicated that young patients had an acute onset of symptoms, the prevalence of stable angina was $4.4 \%, 20.1 \%$ of patients had UA, and more than half of the patients were admitted with MI as the first sign of CAD. Only $24.5 \%$ of the cohort had a history of angina before $\mathrm{Ml}$; this trend is consistent with the results of Imazio et al. [20]. Therefore, CAD identification and intervention before $\mathrm{MI}$ is difficult in unsuspecting young patients.

Single-vessel disease was more common than multiple-vessel disease, and the prevalence of normal or minor coronary artery abnormalities was higher in young patients with CAD [1, 9]. Similarly, we found that young patients with $\mathrm{MI}$ have less extensive $\mathrm{CAD}$, with a significant incidence of single-vessel disease. Also, the incidence of LMCA disease was very low in the young population. Multivessel lesions were present mainly in those who had several risk factors, especially DM. Normal or minor vascular disease was found in $10 \%$ of the patients.

Besides atherosclerotic CAD, non-atherosclerotic CAD or hypercoagulability such as pregnancy, carcinoma, polycythemia, nephrotic syndrome, collagen tissue disorder, oral contraceptive use, antiphospholipid syndrome, and factor $V$ Leiden deficiency should be considered in young cases of MI [1, 2, 21]. Coronary artery spasm, whish is associated that recognise with the use of cocaine and alcohol may also play a role in initiating coronary occlusion and infarction [22, 23]. Non-atherosclerotic spontaneous coronary artery dissection (SCAD) is a rare cause of acute coronary syndrome; young women are at higher risk of SCAD, particularly in the peripartum or early postpartum period [24]. Coronary artery abnormalities are quite rare and it can initially present as $\mathrm{Ml}$ in young adults [25]. A history of congenital coagulation disorders was found in only two patients. Drug use was reported by only seven patients (1.7\%), a lower number than in other studies. It is because of drug use could not be questioned exactly and it was rejected by the social reasons. Connective tissue disorders were not found. The MI prevalence in a normal coronary angiogram was low (approximately 3\%) but seemed to vary with age, with higher rates in young patients [1].
The rate of in-hospital complications and mortality are low in young ACS patients due to their low-risk profile with usually have no concomitant disorders, less severe $C A D$, better cardiac reserve function, and the application of early revascularization with a better response to $\mathrm{PCl}$ $[1,3,5,9,10]$. Consistent with these studies, the rates of complications and mortality during the hospitalization period were low in most of our patients. The compliance to treatment in the hospital and at home was high among patients with CAD (Table 4).

\section{Study limitations}

This study had certain limitations. First, it was done retrospectively, and the data on patients were obtained from medical records, which were incomplete. Second, only conventional risk factors for CAD were evaluated; other, newer risk factors, such as lipoprotein abnormalities, hypercoagulable states, and hyperhomocysteinemia, were not studied. Third, data on the use of cocaine or sympathomimetic agents were not available. Finally, nonatherosclerotic coronary disease was not directly evaluated, and there was no attempt to document the presence of coronary vasospasm by ergonovine stimulation in patients with normal coronary arteries.

\section{Conclusion}

This study emphasized that in a general population of the same age and sex, young patients with CAD were often smokers and overweight. They also had low-HDL cholesterol levels, hypertriglyceridemia, and DM. Patients commonly had an acute onset of symptoms, less extensive $C A D$, and a favorable prognosis. Besides atherosclerotic CAD, non-atherosclerotic CAD, such as congenital coronary abnormalities, coronary aneurysm, coronary dissection, or hypercoagulability, should be considered as an etiologic factor in young patients with MI despite its rare appearance. Consequently, it seems that smoking and components of metabolic syndrome, such as overweight, hypertriglyceridemia, and low HDL-C level, are important modifiable risk factors that community health service providers should focus on to come up with primary measures to prevent heart attacks in young adults.

\section{Conflict of interest(s)}

The Authors declare that there is no conflict of interest. 


\section{Streszczenie}

Wstęp. Coraz więcej młodych osób jest hospitalizowanych z powodu ostrych zespołów wieńcowych (ACS). Wczesna ocena ryzyka ma podstawowe znaczenie w zapobieganiu chorobie wieńcowej (CAD) lub opóźnieniu jej wystąpienia. Badanie przeprowadzono w celu oceny częstości występowania CAD, jej czynników ryzyka, objawów, leczenia oraz rokowania u młodych pacjentów z CAD i porównanie tych danych z odpowiednimi danymi dotyczącymi osób niechorujących na CAD. Materiał i metody. Na potrzeby tego retrospektywnego badaniu zidentyfikowano 4325 chorych poddanych koronarografii w latach 2011-2014. W grupie badanych było 627 chorych w wieku nie więcej niż 45 lat; u 412 osób z tej grupy stwierdzono CAD, a u 215 obraz tętnic wieńcowych był prawidłowy (grupa kontrolna).

Wyniki. Średni wiek chorych wynosił $41,7 \pm 4,1$ roku w grupie CAD i $41,5 \pm 4,5$ roku w grupie kontrolnej. W grupie CAD stwierdzono częstsze występowanie dyslipidemii, palenia tytoniu, dodatniego wywiadu rodzinnego odnośnie do CAD, nadciśnienia tętniczego, cukrzycy i otyłości niż w grupie kontrolnej. Jednak różnica w zakresie częstości występowania otyłości nie była istotna statystycznie. U chorych z ACS często stwierdzano zawał serca z uniesieniem odcinka ST (49,3\%), a dominującym typem zmian w koronarografii była choroba jednonaczyniowa (55,3\%). Najczęściej stosowanym leczeniem reperfuzyjnym $(68,4 \%)$ była przezskórna interwencja wieńcowa.

Wnioski. W badanej grupie młodych pacjentów stwierdzono większą zapadalność na CAD wśród mężczyzn. Najważniejszym poddającym się modyfikacji czynnikiem ryzyka było palenie tytoniu. U dużej części chorych stwierdzono również dyslipidemię, otyłość, cukrzycę i występowanie CAD w rodzinie. Badanie ponownie zwróciło uwagę na zależność między tradycyjnymi czynnikami ryzyka sercowo-naczyniowego a występowaniem CAD w młodym wieku.

Słowa kluczowe: choroba wieńcowa, młodzi dorośli, koronarografia

Folia Cardiologica 2017; 12, 6: 543-550

\section{References}

1. Zimmerman FH, Cameron A, Fisher LD, et al. Myocardial infarction in young adults: angiographic characterization, risk factors and prognosis (Coronary Artery Surgery Study Registry). J Am Coll Cardiol. 1995; 26(3): 654-661, doi: 10.1016/0735-1097(95)00254-2, indexed in Pubmed: 7642855.

2. Doughty M, Mehta R, Bruckman D, et al. Acute myocardial infarction in the young - the University of Michigan experience. Am Heart J. 2002; 143(1): 56-62, doi: 10.1067/mhj.2002.120300, indexed in Pubmed: 11773912.

3. Morillas P, Bertomeu V, Pabón P, et al. PRIAMHO II Investigators. Characteristics and outcome of acute myocardial infarction in young patients. The PRIAMHO II study. Cardiology. 2007; 107(4): 217-225, doi: 10.1159/000095421, indexed in Pubmed: 16953107.

4. Akosah KO, Schaper A, Cogbill C, et al. Preventing myocardial infarction in the young adult in the first place: how do the National Cholesterol Education Panel III guidelines perform? J Am Coll Cardiol. 2003; 41(9): 1475-1479, doi: 10.1016/s0735-1097(03)00187-6, indexed in Pubmed: 12742284.

5. Barbash Gl, White HD, Modan M, et al. Acute myocardial infarction in the young-the role of smoking. The Investigators of the International Tissue Plasminogen Activator/Streptokinase Mortality Trial. Eur Heart J. 1995; 16(3): 313-316, doi: 10.1093/oxfordjournals. eurheartj.a060912, indexed in Pubmed: 7789372.

6. Shiraishi J, Kohno Y, Yamaguchi S, et al. AMI-Kyoto Multi-Center Risk Study Group. Acute myocardial infarction in young Japanese adults. Circ J. 2005; 69(12): 1454-1458, doi: 10.1253/circj.69.1454, indexed in Pubmed: 16308491.

7. Schoenenberger AW, Radovanovic D, Stauffer JC, et al. AMIS Plus Investigators. Acute coronary syndromes in young patients: presentation, treatment and outcome. Int J Cardiol. 2011; 148(3): 300-304, doi: 10.1016/j.ijcard.2009.11.009, indexed in Pubmed: 19942306.

8. Matsis K, Holley A, Al-Sinan A, et al. Differing clinical characteristics between young and older patients presenting with myocardial Infarction. Heart Lung Circ. 2017; 26(6): 566-571, doi: 10.1016/j. hlc.2016.09.007, indexed in Pubmed: 28089789.

9. Shah N, Kelly AM, Cox N, et al. Myocardial infarction in the "young": risk factors, presentation, management and prognosis. Heart Lung Circ. 2016; 25(10): 955-960, doi: 10.1016/j.hlc.2016.04.015, indexed in Pubmed: 27265644.

10. Fournier JA, Sánchez-González A, Quero J, et al. Normal angiogram after myocardial infarction in young patients: a prospective clinical-angiographic and long-term follow-up study. Int J Cardiol. 1997; 60(3): 281-287, doi: 10.1016/s0167-5273(97)00115-0, indexed in Pubmed: 9261639.

11. Kannel W, McGee D, Castelli W. Latest perspectives on cigarette smoking and cardiovascular disease: the Framingham Study. J Card Rehabil. 1984; 4: 267-77.

12. Cullen P. Evidence that triglycerides are an independent coronary heart disease risk factor. Am J Cardiol. 2000; 86(9): 943-949, indexed in Pubmed: 11053704.

13. Li Z, Huang Ji, Li N. Predictive and prognostic value of high-density lipoprotein cholesterol in young male patients with acute myocardial Infarction. Chin Med J (Engl). 2017; 130(1): 77-82, doi: 10.4103/03666999.196581, indexed in Pubmed: 28051027.

14. Mahoney LT, Burns TL, Stanford W, et al. Usefulness of the Framingham risk score and body mass index to predict early coronary artery calcium in young adults (Muscatine Study). Am J Cardiol. 2001; 
88(5): 509-515, doi: 10.1016/s0002-9149(01)01728-3, indexed in Pubmed: 11524059.

15. Uhl GS, Farrell PW. Myocardial infarction in young adults: risk factors and natural history. Am Heart J. 1983; 105(4): 548-553, doi: 10.1016/0002-8703(83)90476-3, indexed in Pubmed: 6837409.

16. Krolewski AS, Kosinski EJ, Warram JH, et al. Magnitude and determinants of coronary artery disease in juvenile-onset, insulin-dependent diabetes mellitus. Am J Cardiol. 1987; 59(8): 750-755, doi: 10.1016/0002-9149(87)91086-1, indexed in Pubmed: 3825934.

17. Malmberg K, Båvenholm P, Hamsten A. Clinical and biochemical factors associated with prognosis after myocardial infarction at a young age. J Am Coll Cardiol. 1994; 24(3): 592-599, doi: 10.1016/0735-1097(94)90002-7, indexed in Pubmed: 8077526.

18. British Heart Foundation. BHF coronary heart disease statistics 2003. http://www.bhf.org.uk/professionals/statistics (2003).

19. Chen L, Chester M, Kaski JC. Clinical factors and angiographic features associated with premature coronary artery disease. Chest. 1995; 108(2): 364-369, doi: 10.1378/chest.108.2.364, indexed in Pubmed: 7634868.

20. Imazio M, Bobbio M, Bergerone S, et al. Clinical and epidemiological characteristics of juvenile myocardial infarction in Italy: the GISSI experience. G Ital Cardiol. 1998; 28(5): 505-512, indexed in Pubmed: 9646064.

21. Mansourati J, Da Costa A, Munier S, et al. Prevalence of factor $V$ Leiden in patients with myocardial infarction and normal coronary angiography. Thromb Haemost. 2000; 83(6): 822-825, indexed in Pubmed: 10896232.

22. Isner JM, Estes NA, Thompson PD, et al. Acute cardiac events temporally related to cocaine abuse. N Engl J Med. 1986; 315(23): 1438-1443, doi: 10.1056/NEJM198612043152302, indexed in Pubmed: 3785295.

23. Huang $\mathrm{CN}$, Wu DJ, Chen KS. Acute myocardial infarction caused by transnasal inhalation of amphetamine. Jpn Heart J. 1993; 34(6): 815-818, doi: 10.1536/ihj.34.815, indexed in Pubmed: 8164349.

24. Neves D, Bento Â, Fernandes R, et al. Spontaneous coronary artery dissection: still a lot to learn. Rev Port Cardiol. 2017; 36(1): 59.e1-59.e5, doi: 10.1016/j.repc.2016.06.012, indexed in Pubmed: 27988230.

25. Harikrishnan S, Jacob SP, Tharakan J, et al. Congenital coronary anomalies of origin and distribution in adults: a coronary arteriographic study. Indian Heart J. 2002; 54(3): 271-275, indexed in Pubmed: 12216922. 